\title{
AN ANALYSIS OF FIGURATIVE LANGUAGE FOUND IN SONG OF BRUNO MARS ENTITLED "GRENADE"
}

\author{
Maudy Yaser Fajrin ${ }^{1}$, Aseptiana Parmawati² \\ 1,2 IKIP Siliwangi \\ ${ }^{1}$ maudy.yaser@student.ikipsiliwangi.ac.id, ${ }^{2}$ aseptiana@ikipsiliwangi.ac.id
}

\begin{abstract}
Individuals use language as a means of communication everywhere and at all times. In today's world, figurative language is often encountered in everyday life, such as in song lyrics. Figurative language is a way of describing something without saying it directly. This research aims to investigate the figurative languages found in the lyrics of the song "Grenade" by analyzing their context and attempting to decipher their meaning. The data tool is song lyrics found on the internet, and the research approach is descriptive qualitative analysis. The results revealed that this album employs figurative language such as metaphor, hyperbole, and repetition. Furthermore, the most figurative words used in the lyrics is hyperbole. Each figurative language's contextual sense is often clarified in relation to the lyric's situation.
\end{abstract}

Keywords: Figurative Language, Song lyrics, Contextual Meaning

\section{INTRODUCTION}

The common thread that binds people and nations is thought to be language. Language helps people to share their thoughts and feelings, as well as form positive relationships with one another. Language is a means of conveying information, whether orally or in writing. Language is used to convey the message from the speaker and the hearer Sabata \& Ibrahim (2018). According to Keraf (2007) in expressing ideas either speaker or writer has a different style as cited in (Ibrahim, Akib, \& Hasyim, 2019). Moreover, Sapir (2010, p. 8) as cited in Ardhyanti \& Supriyatiningsih (2020) defines language as "communication ideas, emotions, and desires" by arguing that language use conveys varied and complex kinds of information group affiliations and relationship with his listener. It implies that language is used to communicate ideas, suggestions, or comments, whether written or spoken.

Sugiono (2013) as cited in Nursolihat \& Kareviati (2020) stated that literally, it's not enough to understand only the form of language and the pronunciation, because it requires understanding the meaning. For this reason, people in the modern era interact in a number of ways, including discussions through literature such as poetry, novels, and song lyrics, which are typically implied in the messages or use figurative language to express the actual meaning of the words.

The figurative language in this analysis is examined through the lyrics of the song "Bruno Mars, entitled Grenade." The researcher wants to look at how people use figurative words. Several research on figurative language have been carried out, as follows: first, previous research by Setiawati \& Maryani (2018) entitled "An Analysis of Figurative Language in Taylor Swift's Song Lyrics", a journal of English Language and Literature Study Program of IKIP Siliwangi Bandung. Using a qualitative approach, the researchers discovered several forms of figurative language including simile, metaphor, hyperbole, symbol, irony, paradox, and personification. 
These findings suggest that hyperbole is the most powerful element in Taylor Swift's music, and that it conveys a message of discord, heartache, and deep treachery based on the meaning of Taylor Swift's overall song lyrics.

Second, research was done by Dewi, Hidayat, \& Alek (2020) entitled "Investigating Figurative Language in Lose You to Love Me Song Lyric", an English Studies Journal. The descriptive qualitative model was used in this study with a strict approach to structuralism, which included hyperbole, irony, paradox, personification, repetition, and simile, with hyperbole being the most prevalent figurative expression.

Third, research by Rahmani (2020) entitled "An Analysis of A Million Dreams Song: Figurative Language And Moral Interpretations", a Jurnal Ilmiah Spectral. The research used a qualitative study. There are 13 imageries, 4 personifications, 2 paradoxes, 14 symbols, 6 idioms, 9 hyperboles, 8 repetitions, 1 simile, 1 metaphor, 1 assonance, and 6 consonances in the figurative language review. The study revealed that the song contained eleven different forms of figurative language as well as two moral principles.

Fourth, a research was done by Nuraeni, Ismail, \& Kareviati (2020) entitled "The Analysis of Figurative Language Used In The Lyric of Awaken By Maher Zain”, a journal of English Language and Literature Study Program of IKIP Siliwangi Bandung. As part of the descriptive qualitative research design, the researcher started by reading the album. The researcher then attempted to decode the meaning of each figurative language use in the song by defining the figurative language-containing words, phrases, and sentences. As a result, certain figurative languages were used in Maher Zain's song Awaken, such as hyperbole, rhetoric, repetition, and personification.

Fifth, research by (Hulu, 2021) entitled "An Analysis of Figurative Language In Ariana Grande's Album Thank U, Next", a Linguistic, English Education and Art (LEEA). The research method used in this analysis was descriptive qualitative research. The researcher discovered 73 data that used figurative language, nine data that used simile, seventeen data that used metaphor, eight data that used personification, ten data that used hyperbole, nine data that used metaphors, four data that used irony, and sixteen data that used idioms. The most popular is a metaphor.

\section{Figurative Language}

Figurative language is the language which "does not refer to the most basic of the concrete meaning of a word or phrase" (Lazar, 2006, p. 3; see also Chamisa, 2004) as cited in Bram \& Avillanova, (2019). In according Kalandadze et al. (2018) as cited in Dewi et al., (2020) argued that figurative language could improve social communication by allowing figurative language masters to change listeners' or readers' perceptions of a word or idea by comparing it to something else. Many theories of figurative language have been proposed by experts, but the writer in this study uses Kennedy's theory. According to Kennedy (1991) as cited in Nursolihat \& Kareviati (2020) identifies eleven different forms of figurative expression. The following forms of figurative language will be discussed in relation to this study and used to analyze the results:

1) A metaphor is a figurative representation of something that is not literal. It does not connect sentences with terms like "like" or "as." 
2) A simile is a comparison of two objects, usually indicated by a connective such as like, as, or than, or a verb such as resembles.

3) Metonymy is the use of a word or expression with a meaning that is very similar to the actual meaning.

4) Synecdoche is when a part of something is used to reflect the whole thing, or vice versa.

5) A transferred epithet is a term used to describe the identity or distinguishing characteristics of someone or something.

6) A figure of speech in which an individual personifies an entity, an animal, or an abstract idea is known as personification.

7) Rhetoric is a figure of speech in which a question is posed that does not require an answer because the answer is already contained within the question.

8) Hyperbole is a form of figurative language in which an exaggerated comment is used to highlight a point.

9) In a given context, repetition refers to the repetition of a tone, syllable, word, or part of a sentence that is considered to be essential for stress.

10) A paradox is a statement that, at first glance, appears to be self-contradictory but, upon further thought, makes sense.

11) Paronomasia is a figurative term that uses various meanings of words to achieve a humorous or rhetorical effect.

\section{Song Lyric}

According to Perrine (1982) as cited in Putu Ratna (2017) fiction, drama, and poetry are three different types of literary work. Poetry is often an important subject to explore among these three forms of literature. Besides, Jumio (2017, p. 172) as cited in Bram \& Avillanova (2019) states that "The use of language with the selection of beautiful and meaningful vocabulary makes a poem interesting to explore". This is due to the fact that poetry can be sung as well as read. Many songwriters are influenced by poetry while writing song lyrics. As a result, the song becomes a part of the work of literature. This time, the writer will discuss the Grenade song, which is one of the singles in Bruno Mars' album, Doo-Wops\&Hooligans and the song was released on September 28, 2010. The song Grenade Bruno Mars tells about a betrayal of love. People who are willing to do anything for their boyfriend. He does not ask his girlfriend to do the same and only asks him to give all of his love. Everything that person does is meaningless and futile.

\section{METHOD}

Descriptive qualitative was used in this research. Qualitative data analysis is typically conducted with the words. Kaswan \& Suprijadi (2016) as cited in Nursolihat \& Kareviati (2020). The aim of this research is to find and analyze some figurative language in the song 
"grenade". This means that this study focuses only on words and interpretation, and does not use statistical techmiques to analyze data.

According to Sandelowski (2000) as cited in Nursolihat \& Kareviati (2020) descriptive qualitative differs from other types of qualitative research, the descriptive rather than interpretive in focus. Since it focuses on the study's data, a thorough overview is usually the result. The researcher specifically observed the lyric "grenade" from Bruno Mars' album. The researcher looked at the song lyrics to see what kind of figurative language was used and what it meant. The focus of the study was on the figurative language in Bruno Mars' song lyric "grenade." The lyric for the song was found on the internet.

The next step after discovering figurative language in the lyric is to examine the context of each figurative language. The last move is to come to a conclusion.

\section{RESULTS AND DISCUSSION}

\section{Results}

The researcher's study of the figurative language found in Bruno Mars' grenade lyrics is seen in this section. In Table 1, you can see how the grenade song uses figurative language:

Table 1

\section{Figurative Language Expression/Lyric}

1. Easy come, easy go, thats just how u live

Metaphor

2. Tell the devil I said 'hey' when u get back to where you are from

3. And you tossed it in the trash

1. Gave you all I had

Hyperbole

2. To give me all your love is all I ever asked

3. I do catch a grenade for you

4. Yes, I would die for you baby

Repetition

1. Take, take, take it all

2. No, no, no, no

3. Black, black, black, and blue

\section{Discussion}

According to Kennedy's (1991) theory, there are three forms of figurative language in grenade song lyrics: metaphor, hyperbole, and repetition.

\section{A. Metaphor}

A methapor is a claim that something is something else that it isn't in the literal sense. It doesn't use words like "like" or "as" to link sentences.

\section{Easy come, easy go, that's just how u live}

This sentence is included in the metaphor, because the sentence "Easy come, easy go, that's just how u live" states that a lover's relationship where his partner can treat whatever she likes and comes when there is a need first and can leave him at any time. 
2. Tell the devil I said 'Hey' when u get back to where you are from

The sentence entered the category of metaphor because contextual menaing is he was comparing the girl to being evil like a devil. He meant that she was mean or tricky.

\section{And you tossed it in the trash}

That sentence is included in a metaphor because the sentence you tossed it in the trash does not actually mean throwing it in the trash but all the sacrifices that he gives to her are meaningless, and just forget about it.

\section{B. Hyperbole}

Hyperbole is figurative language that emphasizes an argument by making an exaggerated comment.

\section{Gave you all I had}

This sentence is categorized as hyperbole because the phrase "Gave you all I had" is exaggerated that he gives everything but he didn't. if he treats her right the wouldn't be heartbroken.

\section{To give me all your love is all I ever asked}

The lyric song used words that produced a very dramatic effect, namely, the desired all of her love, which he stated exaggeratedly. This statement was graded as hyperbole because the lyric song used words that produced a very dramatic effect, namely, the desired all of her love, which he stated exaggeratedly.

\section{I'd catch a grenade for you}

This sentence was classified as hyperbole because the contextual meaning is that he is attempting to prove that he would do anything for her. He's proving that he would do anything to win her forgiveness and come back.

\section{Yes, I would die for u baby}

Because of its over-the-top effect, this sentence qualifies as hyperbole. In fact, the author say, "Yes, I would die for you baby". So that he can look really love her and make her the most valuable.

\section{Repetition}

The repetition of a tone, syllable, word, or part of a sentence that is necessary to give stress in the right sense is referred to as repetition.

\section{Take, take, take it all}

Since the three phrases are repeated, the sentence should be included in the category of repetition. The writer tells of a man frustration at feeling cheated her.

2. No, no, no, no 
Because the lyric is repeated, the sentence is classified as a repetition. The writer poured out the man's sorrow with a sentence "No, no, no, no".

\section{Black, black, black and blue}

Since it repeats the first letters and sounds in the line, the sentence is classified as repetition. The sentence "black and blue" is an idiom of battered.

\section{CONCLUSION}

The study was carried out to examine Bruno Mar's song lyric Grenade. Researchers discovered figurative language in song lyrics as part of their studies. According to Kennedy (1991) as cited in (Nursolihat \& Kareviati, 2020) metaphor, hyperbole, and repetition are the three figurative languages found. Hyperbole was the most common form of figurative language in this song's lyrics. The song grenade Bruno mars tells about betrayal of love. People who would go to any length for his girlfriend. He doesn't ask his girlfriend to do the same and only asks him to give all of his love but everything that person does is meaningless and futile. A song's meaning cannot be deduced from a single word, it must be interpreted in the light of the entire lyrics. In order to know the meaning and understand a word from a song, it is essential to use figurative language to translate the acual ideas and feelings expressed in the lyric.

\section{ACKNOWLEDGMENTS}

Alhamdulillah, all praise may be due to Allah SWT who always blessed me in every second of my life before I complete this paper under the title "AN ANALYSIS OF FIGURATIVE LANGUAGE FOUND IN BRUNO MARS SONG ENTITLED GRENADE". Peace and greeting to our prophet Muhammad SAW who directed us from darkness to lightness. As a result, I'd like to express my heartfelt gratitude to my family, who has always been supportive of me and has never stopped praying for me

Above all, I would like to thank you for my lecture, Aseptiana Parmawati M.Pd for her advice and research know-how for my lecture. Finally, as the writer, to make this paper more perfect, I expect and require more constructive criticism and suggestion from the readers.

\section{REFERENCES}

Ardhyanti, S. V., \& Supriyatiningsih, S. (2020). Figurative Language Analysis in Celine Dion'S Song Lyrics Falling Into You Album. PROJECT (Professional Journal of English Education), 3(1), 11. https://doi.org/10.22460/project.v3i1.p11-19

Bram, B., \& Avillanova, A. A. (2019). Figurative Language in Songs in Student's Book for Senior High School. SOSHUM: Jurnal Sosial Dan Humaniora, 9(3), 247-255. https://doi.org/10.31940/soshum.v9i3.1378

Dewi, E. N. F., Hidayat, D. N., \& Alek, A. (2020). Investigating Figurative Language in "Lose You to Love Me" Song Lyric. Loquen: English Studies Journal, 13(1), 6. https://doi.org/10.32678/loquen.v13i1.2548

Hulu, D. A. (2021). An Analysis of Figurative Language in Ariana Grande 'S Album " Thank U, Next ." 4(1989), 317-327.

Ibrahim, I., Akib, M., \& Hasyim, R. (2019). The analysis of figurative language in "endless love" song lyric. Lisan: Jurnal Bahasa Dan Linguistik, 8(2), 119-130.

Nuraeni, S., Ismail, T., \& Kareviati, E. (2020). the Analysis of Figurative Language Used in the Lyric of Awaken By Maher Zain. PROJECT (Professional Journal of English 
Education), 3(2), 187. https://doi.org/10.22460/project.v3i2.p187-194

Nursolihat, S., \& Kareviati, E. (2020). an Analysis of Figurative Language Used in the Lyric of "a Whole New World" By Zayn Malik and Zhavia Ward. PROJECT (Professional Journal of English Education), 3(4), 477. https://doi.org/10.22460/project.v3i4.p477-482

Putu Ratna, A. (2017). an Analysis of Figurative Language Found in Katy Perry'S Song Entitled "Firework." Lingua Scientia, 24(2), 45. https://doi.org/10.23887/ls.v24i2.18799

Rahmani, E. (2020). an Analysis of 'a Million Dreams' Song : Figurative Languages and Moral Interpretations. Jurnal Ilmiah Spectral, 6(2), 115-123. https://doi.org/10.47255/spectral.v6i2.61

Setiawati, W., \& Maryani, M. (2018). an Analysis of Figurative Language in Taylor Swift'S Song Lyrics. PROJECT (Professional Journal of English Education), 1(3), 261. https://doi.org/10.22460/project.v1i3.p261-268 